\title{
FREKUENSI HUBUNGAN SEKSUAL DAN KB PIL KOMBINASI TERHADAP TERJADINYA EROSI PORTIO PADA WANITA PASANGAN USIA SUBUR
}

\author{
ARTICLE INFO \\ Article history \\ Submitted : 2020-08-03 \\ Revised : 2021-10-19 \\ Accepted : 2021-12-30

\section{Keywords: \\ Sexual intercourse \\ Combined oral \\ Contraceptive pill \\ Portio erosion}

\author{
Yusri Dwi Lestari ${ }^{\bowtie}$, Siti Nur Farida \\ Fakultas Kesehatan Universitas Nurul Jadid
}

\begin{abstract}
Portio erosion is a wound or inflammation of the cervix (portio). Inflammation can be caused by hormonal changes, during pregnancy, contraceptive pill use, installation and removal of IUDs, and lack of personal hygien. This erosion can bleed easily and cause bleeding or metrorrhagia. This study aims to determine the relationship between the frequency of sexual relations and the use of the combined oral contraceptive pill to erosion of portion in reproductive women. This research is an analytic study with a cross sectional design with accidental sampling. Data collection was carried out using interviews and direct observation. Data analysis by a cross tabulation with Spearman Rank test through SPSS software. The results obtained are severe portio erosion covering more than $2 / 3$ of the total cervical area of 8 women $(53 \%)$ based on the frequency of sexual intercourse, and mild portio erosion covers less than $1 / 3$ of the total cervical area of 10 women $(67 \%)$ based on the combined oral contraceptive pill. The study concludes that the frequency of sexual intercourse affected the incidence of portio erosion. The use of the combined oral contraceptive pill has affected the incidence of portio erosion in the POSKESDES Binor Paiton Probolinggo. The results of this study are input for women of childbearing age who are sexually active and use combined pill contraceptives to be more aware of the health of their reproductive organs by routinely performing an IVA or Pap smear at least once a year.

Erosi porsio merupakan luka atau peradangan pada mulut rahim (portio). peradangan dapat disebabkan oleh perubahan hormon, saat kehamilan, penggunaan pil KB, pemasangan dan pelepasan IUD, personal higiene yang kurang. Tempat erosi ini dapat berglanulasi sehingga mudah berdarah dan menimbulkan perdarahan atau metroragia. Penelitian ini bertujuan mengetahui hubungan frekuensi hubungan seksual dan penggunaan KB Pil kombinasi terhadap terjadinya erosi portio pada wanita pasangan usia subur. Penelitian ini merupakan penelitian analitik dengan desain cross sectional dengan accidental sampling. Pengambilan data menggunakan wawancara dan observasi langsung. Pengolahan data dengan tabulasi silang dengan uji spearman rank melalui perangkat lunak SPSS. Hasil yang diperoleh adalah erosi porsi parah yang mencakup lebih dari $2 / 3$ dari total area serviks 8 orang wanita (53\%) berdasarkan frekuensi hubungan seksual. Dan erosi portio ringan mencakup kurang dari $1 / 3$ dari total area serviks 10 orang $(67 \%)$ pada wanita berdasarkan pil KB kombinasi. Kesimpulan penelitian ini adalah ada pengaruh frekuensi hubungan seksual dengan kejadian erosi portio dan ada pengaruh pemakaian KB pil kombinasi dengan erosi portio Di POSKESDES Binor Paiton Probolinggo. Hasil penelitian ini menjadi masukan bagi wanita usia subur yang aktif secara seksual dan menggunakan kontrasepsi pil kombinasi untuk lebih sadar akan kesehatan organ reproduksinya dengan rutin melakukan IVA atau Pap smear minimal 1 kali dalam setahun.
\end{abstract}

Corresponding Author:

Yusri Dwi Lestari

Fakultas Kesehatan Universitas Nurul Jadid

Telp. 082231996680

Email: yusrifkes@gmail.com

\section{PENDAHULUAN}

Masalah kesehatan pada sistem reproduksi wanita bervariasi dari yang ringan sampai berat hingga menyebabkan keganasan. Salah satu masalah kesehatan reproduksi yang banyak dialami wanita adalah erosi porsio (mulut rahim). Erosi portio adalah suatu proses peradangan atau suatu luka yang terjadi pada daerah portio serviks uteri (mulut rahim) (Purwoastuti, 2015). Erosi porsio merupakan penyakit tidak menular yang muncul sebagai masalah kesehatan yang perlu dilakukan 
pengendalian yang tepat. Erosi porsio adalah salah satu kondisi ginekologis yang di derita sekitar 85\% wanita (Neelam and Kumar, 2009).

Erosi porsio (serviks) sering kali tanpa gejala. Erosi portio merupakan masalah kesehatan reproduksi yang menyebabkan infeksi pada saluran reproduksi, yang mana angka kejadian inspeksi saluran reproduksi (ISR) tertinggi di dunia adalah pada usia remaja (35\%-42\%) dan menoupose (30\%-35\%). Di Indonesia wanita yang mengalami erosi portio sebanyak 15,02\% (DepKes RI, 2014).

Meskipun tidak fatal, namun risiko jangka panjang dari erosi porsio berhubungan dengan gejala yang berkaitan dengan sistem genitourinari, ketidakseimbangan psikologis pada pasien. Erosi porsio dapat menjadi penyebab banyak gejala ginekologis seperti keputihan, sakit punggung, dyspaurenia, perdarahan intermenstrual, dan iritabilitas kandung kemih. Erosi porsio yang tidak segera mendapat penanganan kemudian akan terjadi cervicitis.

Erosi portio dapat disebabkan oleh beberapa hal yaitu, wanita yang menikah usia muda atau berhubungan seksual di usia $<20$ tahun dimana sel mukosa pada serviks belum matang dan masih rentan ketika menerima rangsangan saat berhubungan seksual termasuk zat-zat yang terkandung dalam cairan ejakulat. Penggunaan kontrasepsi oral dalam jangka waktu yang lama lebih dari 4 tahun dapat menyebabkan munculnya lesi pra kanker. Kebersihan organ reproduksi juga berpengaruh terhadap terjadinya erosi portio, kebersihan organ reproduksi berpengaruh terhadap $\mathrm{Ph}$ vagina dan kelembapan sehingga dapat memberikan peluang untuk pertumbuhan jamur dan bakteri, sehingga menyebabkan gatal dan radang yang dapat meningkatkan risiko terjadinya erosi serviks (Simon, 2019).

Erosi serviks sangat umum ditemukan dalam kehamilan karena level estrogen yang tinggi dan akan hilang seiring turunnya kadar estrogen setelah melahirkan. Wanita yang menggunakan kontrasepsi kimiawi juga berisiko mengalami erosi portio akibat perubahan tingkat keasaman daerah genitalia dan alergi pada penggunaan kontrasepsi kimiawi. Penggunaan tampon dan tindakan atau pemeriksaan yang menggunakan speculum juga dapat menyebabkan erosi akibat gesekan benda tersebut dengan portio (Manuaba, 2005). Penggunaan alat kontrasepsi dalam rahim
(AKDR) dapat menyebabkan terjadinya erosi portio pada wanita. Pada saat pemasangan alat kontrasepsi dalam rahim mungkin dapat terjadi sedikit luka atau erosi pada portio atau gesekan benang AKDR dalam waktu yang lama dan dianggap benda asing oleh tubuh sehingga menimbulkan reaksi inflamasi (Handayani. S, 2010).

Hubungan seksual yang aktif juga dapat menjadi faktor predisposisi terjadinya erosi portio pada wanita, hal tersebut dikarenakan seringnya terjadi gesekan pada saat berhubungan seksual dapat menyebabkan luka atau erosi, termasuk juga reaksi yang di timbulkan akibat zat yang terkandung di dalam sperma yang dianggap benda asing dan memperparah luka atau erosi yang sebelumnya telah terjadi (Manuaba, 2009). Maturasi serviks juga berkaitan dengan terjadinya erosi pada portio, hal tersebut dapat terjadi pada wanita yang menikah atau aktif berhubungan seksual pada usia muda dimana serviks belum matang dan masih rentan, kebiasaan merokok dan penggunaan kontrasepsi pil yang mempengaruhi regulasi hormonal di dalam tubuh juga merupakan faktor yang menyebabkan erosi porsi (Hwang Loris et.al, 2009)

Pemakaian kontrasepsi hormonal dan riwayat IMS meningkatkan risiko lesi prakanker leher rahim. Selain itu umur di atas 35 tahun, pertama kali berhubungan seksual pada usia dini dan perilaku seksual berisiko juga meningkatkan risiko terjadinya lesi pra-kanker leher rahim (parwati, dkk., 2015).

Portio yang merupakan ujung dari serviks yang terletak pada bagian paling bawah dari rahim terdiri dari kolagen, elastin dan preteoglikan dengan sedikit otot polos. Portio yang sehat memiliki fungsi menghalangi bakteri agar tidak masuk ke rahim dan sistem reproduksi interna lainnya (Cuningham, et.al, 2013), namun jika kondisi portio mengalami erosi, radang atau gangguan akan berubah menjadi tempat berkembangnya bakteri dan dapat menyebar ke dalam rahim dan organ reproduksi di sekitarnya (Wiknjosastro, 2009).

Porsio yang mengalami erosi dan peradangan berwarna merah disertai dengan timbulnya mucus yang purulen. Erosi yang dibiarkan akan menyebabkan berbagai gangguan pada kesehatan reproduksi wanita, menyebabkan ketidaknyamanan, gangguan pada keharmonisan hubungan suami istri, dan 
akibat paling berat dari erosi yang tidak tertangani dengan baik yaitu munculnya ca cerviks (Norwitz Errol. R, 2007).

Pemeriksaan inspeksi visual asam asetat (IVA) dan Pap smear dapat digunakan untuk mendeteksi kelainan pada serviks. Dengan tidak adanya ketersediaan Pap smear, IVA mungkin merupakan metode skrining kelainan pada serviks dan kanker serviks dengan tindakan yang lebih sederhana dan biaya yang murah (Naz and Hanif, 2014). Berdasarkan latar belakang di atas peneliti melakukan penelitian tentang hubungan frekuensi hubungan seksual dan KB pil kombinasi terhadap terjadinya erosi portio pada wanita pasangan usia subur di poskesdes Binor Paiton Probolinggo.

\section{METODE PENELITIAN}

\section{Jenis Penelitian}

Penelitian ini adalah penelitian observasional dengan rancangan cross sectional untuk mencari hubungan frekuensi hubungan seksual dan KB Pil kombinasi terhadap terjadinya erosi portio pada wanita pasangan usia subur.

\section{Lokasi dan Waktu Penelitian}

Penelitian ini dilakukan di Poskesdes Binor, Paiton, Probolinggo pada Bulan Februari 2020.

\section{Populasi dan Sampel}

Populasi dalam penelitian ini adalah semua pasangan usia subur khususnya wanita yang melakukan pemeriksaan IVA pada bulan
Februari sebanyak 112 orang. Sampel diambil menggunakan purposive sampling. Sampel sebanyak 30 orang dengan masing-masing kelompok sebanyak 15 orang, yaitu kelompok wanita usia subur yang menggunakan kontrasepsi pil kombinasi dalam waktu yang lama namun tidak rutin berhubungan seksual dan wanita usia subur rutin berhubungan seksual minimal $1-2$ kali atau lebih dan menggunakan kontrasepsi non hormonal.

\section{Pengumpulan Data}

Pengumpulan data pada penelitian ini dengan menggunakan observasi melalui pemeriksaan IVA dan wawancara pada wanita pasangan usia subur (WPUS). Pada kelompok KB Pil kombinasi disarankan untuk tidak berhubungan seksual selama seminggu sebelum pemeriksaan IVA.

\section{Pengolahan dan Analisis Data}

Analisa data secara univariat dan bivariat dengan menggunakan program SPSS.

\section{HASIL PENELITIAN}

Berdasarkan tabel 1, responden yang melakukan hubungan seksual $1-2$ kali seminggu sebanyak 4 orang (27\%), 3 - 4 kali seminggu sebanyak 11 orang $(73 \%)$, dan $\geq 5$ kali seminggu 0 orang $(0 \%)$. Responden yang menggunakan KB Pil kombinasi $<5$ tahun sebanyak 3 orang (20\%), 5 tahun sebanyak 1 orang $(7 \%),>5$ tahun sebanyak 11 orang $(73 \%)$.

Tabel 1. Distribusi Frekuensi Responden berdasarkan Frekuensi Hubungan Seksual, Pengunaan KB Pil Kombinasi, dan Erosi Portio

\begin{tabular}{lcc}
\hline \multicolumn{1}{c}{ Variabel } & Frekuensi (n) & Persentase (\%) \\
\hline Frekuensi Hubungan Seksual & & \\
1 - 2 kali seminggu & 4 & 27 \\
3 - 4 kali seminggu & 11 & 73 \\
5 kali seminggu & 0 & 0 \\
\hline Penggunaan KB Pil Kombinasi & 3 & 20 \\
< 5 Tahun & 1 & 7 \\
5 Tahun & 11 & 73 \\
> 5 Tahun & & \\
\hline Erosi Portio berdasarkan Frekuensi Hubungan & 3 & 40 \\
Ringan: $\leq 1 / 3$ total area serviks & 6 & 40 \\
Sedang: $1 / 3$ - 2/3 total area serviks & 6 & 67 \\
Berat: $\geq 2 / 3$ total area serviks & & 20 \\
\hline Erosi Portio berdasarkan KB Pil Kombinasi & 10 & 13 \\
Ringan: $\leq 1 / 3$ total area serviks & 3 & \\
Sedang: $1 / 3$ - $2 / 3$ total area serviks & 2 & \\
Berat: $\geq 2 / 3$ total area serviks & & \\
\hline
\end{tabular}


Responden yang mengalami erosi porsio ringan berdasarkan frekuensi hubungan sebanyak 3 orang (20\%), yang mengalami erosi porsio sedang sebanyak 6 orang (40\%), yang mengalami erosi porsio berat sebanyak 6 orang $(40 \%)$.
Responden yang mengalami erosi porsio ringan berdasarkan KB Pil Kombinasi sebanyak 10 orang (67\%), yang mengalami erosi porsio sedang sebanyak 3 orang (20\%), yang mengalami erosi porsio berat sebanyak 2 orang $(53 \%)$.

Tabel 2. Tabulasi Silang Frekuensi Hubungan Seksual dan Penggunaan KB Pil Kombinasi terhadap Kejadian Erosi Portio

\begin{tabular}{ccccc}
\hline Variabel Penelitian & \multicolumn{3}{c}{ Erosi Portio } & \multirow{2}{*}{ Total } \\
\cline { 2 - 4 } & Ringan & Sedang & Berat & \\
\hline Hubungan Seksual & & 1 & 1 & 4 \\
$1-2$ kali & 2 & 5 & 5 & 11 \\
$3-4$ kali & 1 & 0 & 0 & 0 \\
\hline 5 kali & 0 & 6 & 6 & 15 \\
\hline Total & 3 & & & \\
\hline Penggunaan KB Pil & & 0 & 0 & 4 \\
Kombinasi & 4 & 3 & 2 & 11 \\
$<5$ Th & 6 & 3 & 2 & 15 \\
\hline 5 Th & 10 & & &
\end{tabular}

Berdasarkan hasil tabulasi silang kemudian dilakukan perhitungan dengan menggunakan uji SPSS dengan spearman's rho dan diperoleh hasil 0.037 dan lebih kecil dari $\alpha=0.05$ pada taraf signifikan. Dapat diartikan bahwa ada hubungan antara frekuensi hubungan seksual dengan erosi portio.

Berdasarkan hasil tabulasi silang kemudian di lakukan perhitungan menggunakan uji SPSS dengan spearman's dan diperoleh hasil 0.021 dan lebih kecil dari $\alpha=0.05$ pada taraf signifikan maka dapat diartikan ada hubungan antara KB Pil kombinasi dengan erosi portio.

\section{PEMBAHASAN}

\section{Pengaruh hubungan seksual terhadap erosi portio}

Dari tabel tabulasi silang menunjukkan bahwa hampir setengah responden yang melakukan hubungan seksual 4-6x mengalami erosi berat sebanyak 4 orang (27\%), dan sebagian besar $>6 \mathrm{x}$ mengalami erosi ringan sebanyak 5 orang, erosi sedang sebanyak 2 , erosi berat sebanyak 8 orang dengan jumlah 11 orang $(73 \%)$. Adapun faktor yang mempengaruhi erosi portio adalah frekuensi hubungan seksual, adanya rangsangan pada kanalis servikalis, rangsangan dari luar seperti pemasangan dan pelepasan alat kontrasepsi alam rahim, hubungan seksual serta personal higiene yang kurang dapat menyebabkan radang dan erosi. Tempat erosi ini dapat berglanulasi sehingga mudah berdarah dan menimbulkan perdarahan atau metroragia. Frekuensi hubungan seksual yang tinggi menyebabkan seringnya terjadi gesekan terhadap mukosa portio yang menyebabkan terjadinya erosi pada portio. Zat-zat yang terkandung di dalam sperma juga dapat mempengaruhi mukosa serviks, terutama pada serviks yang luka sehingga dapat memperparah kondisi erosi dan jika terus berlanjut sel-sel mukosa dapat berubah sifat menjadi sel kanker. Selain itu, hubungan seksual yang kasar, hubungan seksual pada saat wanita belum bergairah juga menambah risiko terjadinya lecet dan erosi pada portio.

Frekuensi hubungan seksual dan kejadian erosi Di Poskesdes Binor Paiton Probolinggo di lakukan perhitungan dengan menggunakan uji SPSS dengan spearman's rho (pada lampiran) dan diperoleh hasil 0.037 dan lebih kecil dari p.0.05 pada taraf signifikan maka $\mathrm{H}_{\mathrm{a}}$ diterima berarti ada hubungan antara frekuensi hubungan seksual dengan erosi portio. Hal ini dibuktikan dengan hasil kuesioner responden yang menjawab dan hasil observasi menggunakan pemeriksaan IVA. 
Berdasarkan hasil penelitian yang dilakukan bahwa tingginya frekuensi hubungan seksual menjadi salah satu penyebab terjadinya erosi portio. Salah satu cara untuk mencegah terjadinya erosi serviks berlanjut ke tahap selanjutnya yaitu tetap menjaga kebiasaan hidup yang baik dan bersih, berhubungan seksual yang aman, dan juga melakukan pemeriksaan dini yaitu pemeriksaan pap smear atau pemeriksaan IVA.

\section{Penggunaan KB Pil kombinasi terhadap terjadinya erosi portio}

Erosi porsio ini biasanya ditemukan secara kebetulan pada pada pemeriksaan ginekologi. Berdasarkan hasil penelitian yang telah dilakukan diperoleh hasil bahwa ada pengaruh penggunaan alat kontrasepsi oral dengan terjadinya erosi serviks dengan nilai $\mathrm{p}=0,000 \quad(\mathrm{p}<0,05)$ (Anna, 2012). Penelitian ini sesuai dengan teori yang dikemukakan oleh Megadhana (2014), bahwa kontrasepsi oral yang dipakai dalam jangka panjang lebih dari 4 tahun dapat meningkatkan risiko pra kanker leher rahim sebesar 1,5 - 2,5 kali.

Dari Tabel tabulasi silang Menunjukkan bahwa sebagian kecil responden yang menggunakan $\mathrm{kb}$ pil kombinasi $<5$ tahun mengalami erosi ringan sebanyak 4 orang dengan (27\%), dan sebagian besar $>5$ tahun mengalami erosi ringan sebanyak 6 orang, erosi sedang sebanyak 3 orang, erosi berat sebanyak 2 orang dengan jumlah 11 orang $(73 \%)$. Berdasarkan hasil tabulasi silang kemudian di lakukan perhitungan menggunakan uji SPSS dengan spearman's rho (pada lampiran) dan diperoleh hasil 0.021 dan lebih kecil dari p.0.05 pada taraf signifikan berarti tiada hubungan antara KB Pil kombinasi dengan erosi portio. Kontrasepsi Oral Kombinasi mengandung hormon estrogen dan progesteron. Paparan estrogen dalam waktu yang lama dapat menyebabkan hyperplasia endometrium, dan biasanya disertai perdarahan abnormal. Akibatnya, terjadi peradangan pada serviks. Peningkatan kadar hormon estrogen juga menyebabkan serviks membengkak akibat bertambahnya jumlah pembuluh darah, sehingga rentan terjadi luka dan erosi. Progesteron adalah hormon yang disekresi oleh korpus luteum, plasenta dan sejumlah kecil dari folikel. Progesterone berperan dalam organ reproduksi termasuk kelenjar mamae dan endometrium. Pil kombinasi bekerja dengan cara menekan ovulasi, mencegah implantasi, dan mengentalkan lendir serviks sehingga sulit dilalui sperma. (Narulita dan Prihatin, 2019).

Untuk mencegah terjadinya erosi serviks pada pengguna kontrasepsi termasuk kontrasepsi oral kombinasi harus rutin memeriksakan diri ke puskesmas untuk mengetahui efek dari kontrasepsi yang digunakan.

\section{KESIMPULAN DAN SARAN}

Wanita pasangan usia subur berdasarkan frekuensi hubungan seksual $4-6 x$ seminggu sebanyak 11 orang $(73 \%)$, wanita pasangan usia subur berdasarkan KB Pil kombinasi responden menggunakan $\mathrm{KB}>5$ tahun sebanyak 11 orang (73\%), responden erosi portio berdasarkan frekuensi hubungan seksual mengalami erosi berat meliputi $\geq 2 / 3$ total area serviks sebanyak 8 orang $(53 \%)$. Sebagian besar responden erosi portio berdasarkan KB pil kombinasi mengalami erosi ringan meliputi $\leq 1 / 3$ total area serviks sebanyak 10 orang (67\%). Hasil uji SPSS dengan spearman's rho menunjukkan ada pengaruh frekuensi hubungan seksual terhadap kejadian erosi portio dan ada pengaruh penggunaan KB pil kombinasi dan kejadian erosi portio.

Perlu dilakukan penelitian lanjutan dengan jumlah sampel yang lebih besar, dan perlu adanya pendidikan kesehatan kepada wanita usia subur tentang erosi portio dan perawatan organ reproduksi untuk mencegah terjadinya erosi portio.

\section{DAFTAR PUSTAKA}

Cuningham, et.al. (2013). Obstetri Williams. Penerbit Buku Kedokteran. EGC. Jakarta.

Handayani, S. (2010). Pelayanan Keluarga Berencana. Jakarta: Pustaka Rihama.

Hwang, YL., Ma, YF., Benningfield, SM., Clayton, L., Hanson, EN.,, jay, J., Jonte, J., Medina, CG., Moscicki, AB. (2009). Factors that influence the rate of epithelial maturation in the cervix of healthy young women. $J$ Adolesc Health. 44(2): 103-110.

Manuaba, I.B.G. (2005). Ilmu Kebidanan, Penyakit Kandungan dan Keluarga Berencana Untuk pendidikan Bidan. Jakarta. EGC.

Manuaba, I.B.G. (2009). Memahami Kesehatan Reproduksi Wanita. Jakarta: EGC 
Narulita, E., dan Prihatin, J. (2019). Kontrasepsi Hormonal : Jenis, Fisiologi, dan Pengaruhnya Bagi Rahim. Jember. UPT Penerbitan Universitas Jember.

Naz, U., and Hanif, S. (2014). Agreement Between Visual Inspection WihAceic Acid and Papanicolaou's Smear as Screening Methods for Cervical Cancer. Journal of The College of The Physicians and Surgeons Pakistan.24(4):228-231.

Neelam, Kumar N. (2009) Management of cervical erosion. AYU. 30(2):171-174.

Norwitz Errol. R. (2007). At A Glance Obstetri dan Ginekologi. Alih Bahasa Artsiyanti. Jakarta: Penerbit Erlangga dan Pusat Perbukuan Depdiknas.

Parwati, N., Putra A. E., Karmaya, M. (2015). Kontrasepsi Hormonal dan Riwayat
Infeksi Melular Seksual Sebagai Faktor Risiko Lesi Pra-kanker Leher Rahim. Public Health Preventive Medicine Archieve. 3(2): 138-142.

Purwoastuti, E., Elisabeth, SW. (2015) Panduan Materi Kesehatan Reproduksi dan Keluarga Berencana. Yogyakarta: Pustaka Baru Press.

Simon, M. (2019). Analisis Faktor yang Berpengaruh terhadap Terjadinya Erosi Serviks pada Wanita Pasangan Usia Subur (PUS) di Puskesmas Pallangga Kabupaten Gowa. Nursing Inside Community. 2(1) :1-11. 